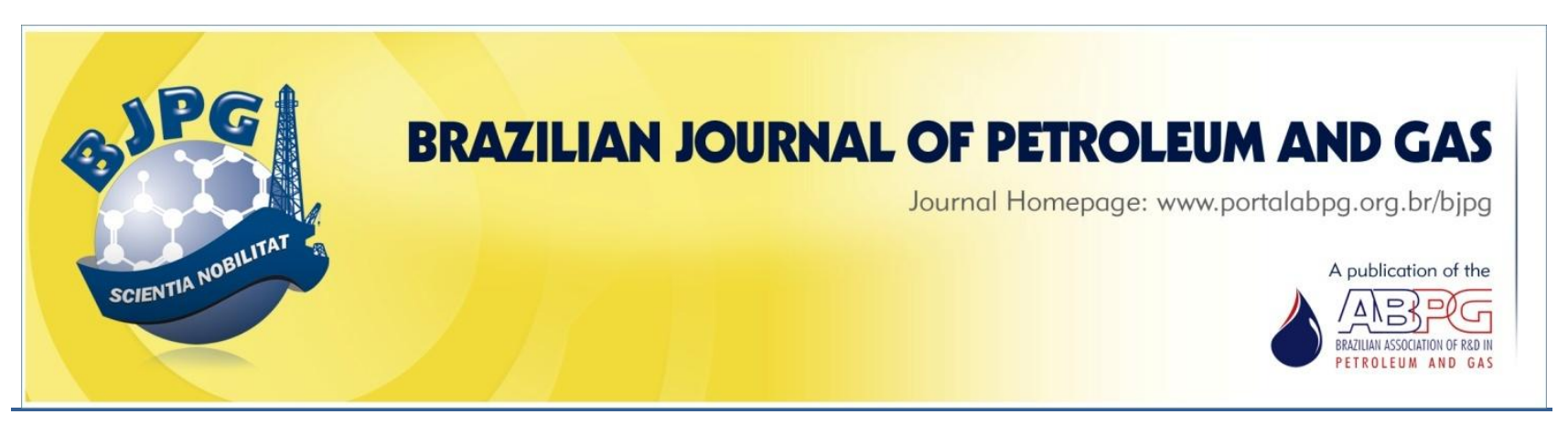

\title{
EXTRACTION AND CHARACTERIZATION (COMPOSITIONAL AND THERMAL) OF ASPHALTENES FROM BRAZILIAN VACUUM RESIDUES
}

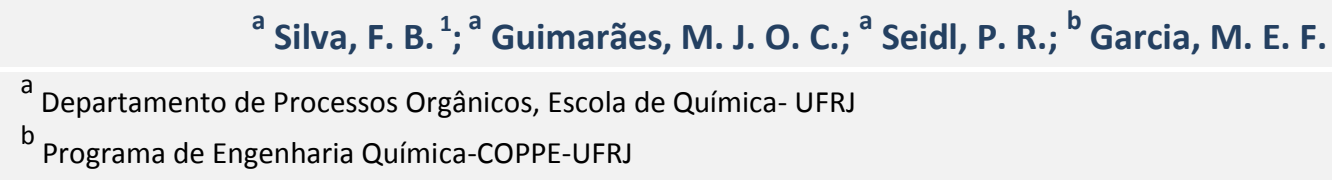

\section{ABSTRACT}

Due to the decrease in light oil reserves, the petroleum industry faces the challenge of developing technologies for processing raw materials and wastes from heavy crude oils, which contain large amounts of asphaltenes. Thus, there is an increasing need to use heavy fractions efficiently in the production of fuels and chemical raw materials. The search for means for removing asphaltenes are justified by the fact that these molecules increase the viscosity of the fractions submitted to distillation, contribute to the formation of coke, and deactivate catalysts used in refining processes. This paper presents an alternative technique for selective extraction of asphaltenes from two Brazilian vacuum residues and compares these results to the ones observed using the IP-143 standard methodology. The extracted fraction was characterized by hydrogen nuclear magnetic resonance $\left({ }^{1} \mathrm{H}-\mathrm{NMR}\right)$ and thermogravimetry (TG/DTG), revealing that the chemical species extracted using different techniques exhibited very small differences in composition but similar thermal behavior.

\section{KEYWORDS}

vacuum residue; selective extraction; asphaltenes; ${ }^{1} \mathrm{H}-\mathrm{NMR}$; thermogravimetry

\footnotetext{
${ }^{1}$ To whom all correspondence should be addressed.

Address: Escola de Química, Universidade Federal do Rio de Janeiro, Av. Horácio Macedo 2030, Centro de Tecnologia, Bloco E, Ilha do Fundão, Rio de Janeiro, RJ - Brazil, Zip code: 21941-909

Fax: +55 21 2562-7285/+55 21 2562-7583| E-mail: fernanda@eq.ufri.br doi:10.5419/bjpg2013-0009
} 


\section{INTRODUCTION}

Supplies of conventional petroleum have been steadily dwindling, increasing the demand for heavier crudes and processes that are able to recover lighter fractions from residues (Strausz, 1999). Asphaltenes are among the constituents of heavy crude oils that have attracted worldwide interest because they present major technical problems, representing a challenge for the petroleum industry, being responsible for major losses in all stages of oil production.

Particularly in Brazil, where most of the fields presently under exploration yield crude oils under $20{ }^{\circ} \mathrm{API}$, refining operations require considerable investments in additional units. The development of more efficient chemical processes for the conversion of highly aromatic and naphthenic constituents into smaller paraffinic moleculeswhich can be separated into fuels, lubricants, or petrochemical raw materials- are a must.

To understand better the phenomenon of dispersion and precipitation of asphaltenes in Brazilian oils, the present group of researchers has been working on the development of more selective alternatives of extraction techniques. The group is focusing on investigating techniques that are better suited for this type of oil (Silva et al., 2010; Seidl et al., 2011; Navarro et al., 2012). The aim of this study is to test an alternative technique for selective extraction of asphaltenic fractions from two types of Vacuum residues, and to compare these results with those obtained by the IP- 143standard method of extraction.

\section{PETROLEUM CONSTITUENTS}

Fractions of these constituents usually are characterized by SARA analysis as saturates (alkanes, cycloparaffins), aromatics (mono, di, and polyaromatic hydrocarbons), resins (constituent fractions of polar molecules containing $\mathrm{N}, \mathrm{O}$, or $\mathrm{S}$ heteroatoms), and asphaltenes (structures similar to resins, which possess higher molar mass and polyaromatic cores if compared to those ones) (Aske et al., 2001; Hernández \& Jorge, 2011). Depending on the content of these constituents, the oil can be classified as shown in Table 1 .
Table 1. Classification of crude oil.

\begin{tabular}{cc}
\hline Classification of Oil & ${ }^{\circ}$ API \\
\hline Light & $\geq 31$ \\
Intermediate & $31>{ }^{\circ} \mathrm{API} \geq 22$ \\
Heavy & $22>{ }^{\circ} \mathrm{API}>10$ \\
\hline Source: ANP, 2012 &
\end{tabular}

\subsection{Asphaltenes}

Asphaltenes are very complex macromolecules containing condensed aromatic and saturated rings, aliphatic chains, and heteroatoms (Murgich, 2002). They correspond to fractions insoluble in paraffinic hydrocarbons, such as n-heptane, but soluble in aromatics such as toluene (Speight, 1999, 2006).

Even in low concentrations, asphaltenes (the main constituents of heavier fractions) have a tendency to aggregate and precipitate, causing major damage in the petroleum industry (Rogel et al., 2001; Goual \& Firoozabadi, 2002; Silva et al., 2010) and, at times, posing serious problems for upstream operations. Asphaltenes may also form coke when heated, and can concentrate heteroatoms, such as nitrogen, that may deactivate catalysts used in conversion processes (Calemma et al., 1998; Ancheyta et al., 2010). On the other hand, because they are rather large and contain aromatic, napththenic and paraffinic groups, solvents of these types or their mixtures offer a certain degree of selectivity to their fractionation (Seidl, 2004).

The structure of asphaltene molecules and the size of the aromatic ring system have been a topic of much discussion among researchers. So far, a defined chemical structure for the asphaltenes has not been completely elucidated, and two distinct models have been proposed (Figure 1). The "island" model is a monomeric structure with a molecular weight in the range of 500-1000 Da, comprising six or more aromatic rings linked together, surrounded by several aliphatic groups, and may contain heteroatoms. The "archipelago" model proposes that the asphaltene molecules are polymeric, formed by individual monomers of polycondensed groups with five to seven aromatic rings linked by aliphatic side chains, possibly 


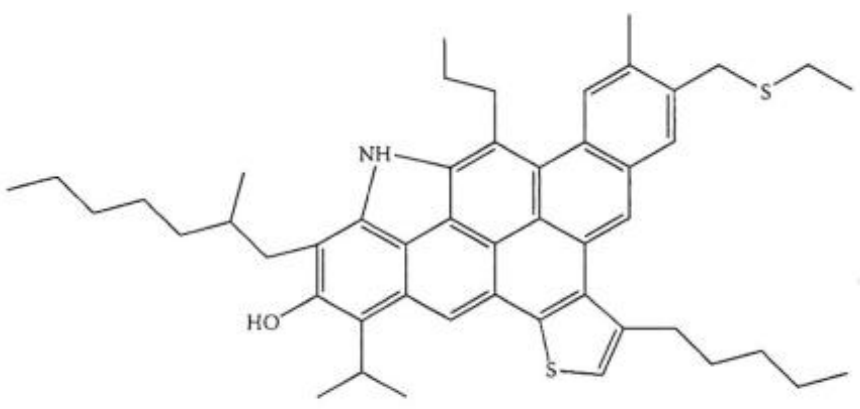

(a)

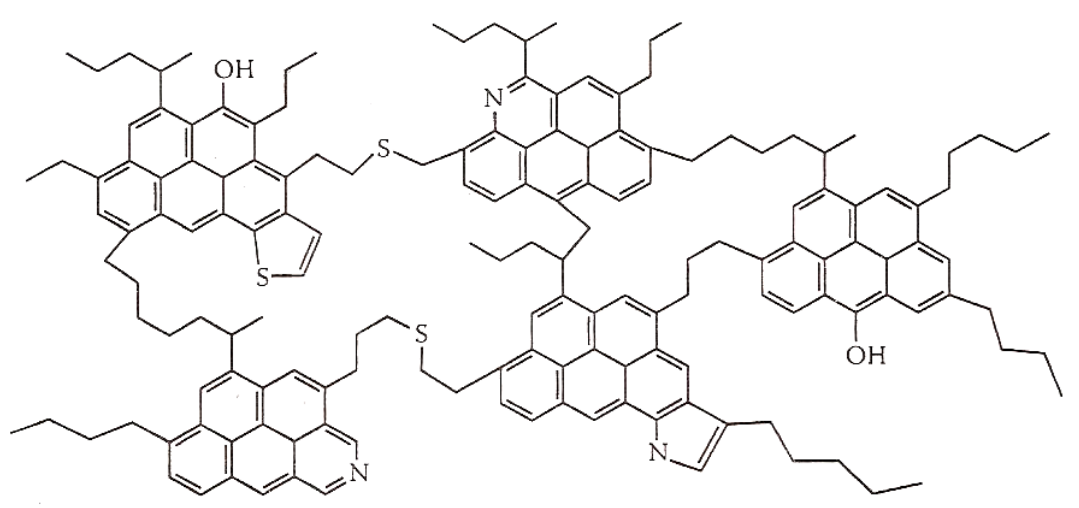

(b)

Figure 1. (a) "Island model" asphaltene molecular architecture; (b) "Archipelago model" asphaltene molecular architecture (Kelland, 2009).

containing polar heteroatoms linked by aliphatic side chains that may contain polar heteroatom bridges (Kelland, 2009).

Recent studies (Mullins, 2010; Mullins et al., 2012; Ramírez \& Morales, 2013) indicate that the dominant molecular architecture for asphaltenes is the one described in the "island model" type, with one aromatic ring system per molecule, with a weight of approximately $750 \mathrm{~g} / \mathrm{mol}$ (Da).

\section{MODELS FOR MOLECULAR STRUCTURE OF CRUDE OIL COMPONENTS}

In trying to solve the various problems caused by asphaltenes, it is necessary to understand these complex structures found in the oil. Over the years, several investigators have studied not only properties and characteristics of various types of asphaltenes, but have proposed models to justify the aggregate form of these compounds.

\subsection{Pfeifer and Saal Model (1939)}

This model suggests that asphaltenes coexist and interact with macromolecules present in the oil, such as resins, and form a core of micelles stabilized in a process known as peptization. This process is due to the high polydispersity of asphaltenes, which ensures the start of the formation of nanocluster asphaltenes from less soluble molecular fractions, whereas the more soluble fractions (resins) ensure the completion of the growth of nanoaggregates, generating stable colloidal suspensions (Garreto, 2011). This model has been widely questioned by researchers because, as of yet, it has not been possible to prove conclusively that the resins are responsible for the dispersion of asphaltenes in oil.

\subsection{Yen Model (1960)}

In 1967, Professor Teh Fu Yen revolutionized the study of asphaltenes. This study considered the 


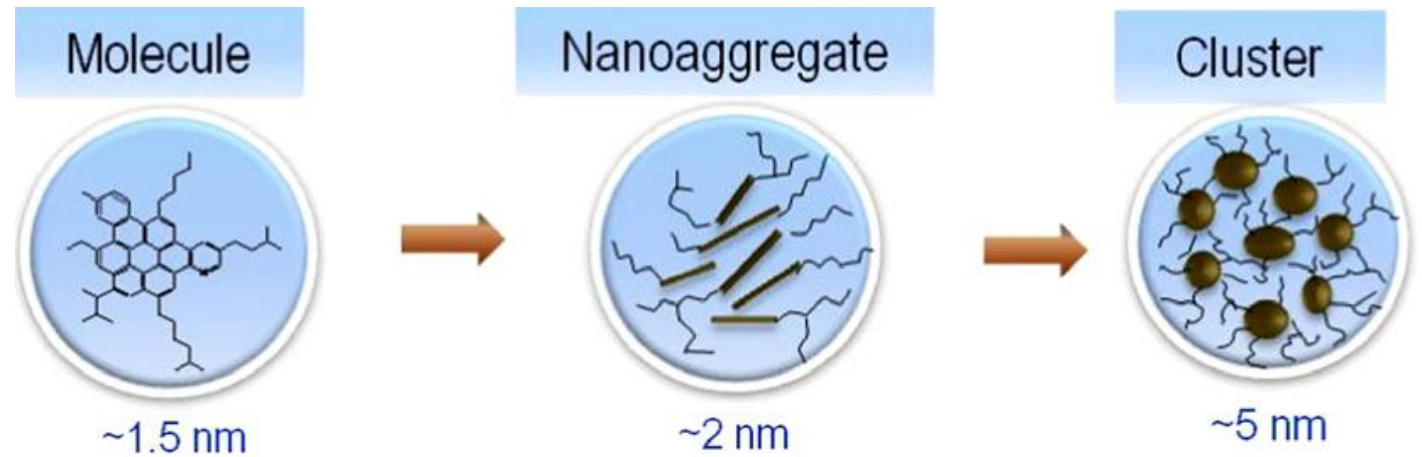

Figure 2. The modified Yen model (Goual et al., 2011; Mullins, 2010).

properties of asphaltenes according to different scales and orders of magnitude. In this model, the resins are substances that are not as heavy or polar as asphaltenes, which show a propensity to aggregate but would provide some kind of peptization that would keep asphaltenes suspended. These asphaltene-resin complexes would reach a critical concentration described above and still form larger aggregates (Dickie \& Yen, 1967; Alburqueque et al., 2005).

The Yen model has been used widely in the past 40 years, particularly for considering bulk properties of phase-separated asphaltenes. Nevertheless, at the time the Yen model was proposed, there were many uncertainties in asphaltene molecular weight, architecture, and colloidal structure (Goual, 2012).

\subsection{The Modified Yen Model}

Significant developments in the science of asphaltenes led to a new model, presented by Mullins (2010). The Modified Yen model stipulates the dominant asphaltene molecular architecture, and its role in forming nanoaggregates and their respective clusters (Mullins, 2010).

The molecular structure of asphaltenes contains a polycyclic aromatic hydrocarbon (PAH) with peripheral alkane substituents. These molecules can form asphaltene nanoaggregates with a single, disordered stack of PAHs and with aggregation numbers $\sim 6$. The periphery of the nanoaggregate is dominated by alkane substituents. These nanoaggregates can form clusters not much bigger than the nanoaggregates, and their aggregation numbers are estimated to be around eight nanoaggregates (Figure 2).
Sum frequency generation (SFG), Brewster angle microscopy (BAM), atomic force microscopy (AFM), and the time-resolved fluorescence diffusion (TRFD) tests were carried out, confirming that transitions from nanoaggregates to clusters occur at the expected concentrations, the thickness of nanoaggregate Langmuir-Blodgett films are found to be $2 \mathrm{~nm}$, and that the island molecular architecture is predominant, with one polycyclic aromatic hydrocarbon surrounded by six fused aromatic rings per molecule of asphaltene.

The multiple modes of interaction of asphaltene aggregates, such as aromatic stacking, hydrogen bonding, acid-base interaction, hydrophobic interaction, and metal binding are illustrated in Figure 3.

\section{SOLUBILITY PARAMETER AND EXTRACTION TECHNIQUES}

The solubility parameter (Equation 1) represents the interaction in condensed materials and provides a numerical method for prediction of degree of interaction. The most common method consists in dissolving the material in various solvents with known solubility parameters. In this case, the solubility parameter of the material is equal to the solubility parameter of the solvent in which it is subjected to larger interaction/solubilization (Hildebrand et al., 1970).

$\delta=\gamma^{*} V^{1 / 2}$

Where:

$\delta=$ Hildebrand Solubility Parameter

$\gamma=$ Surface Tension

$\mathrm{V}=$ Molar Volume of the Solvent 


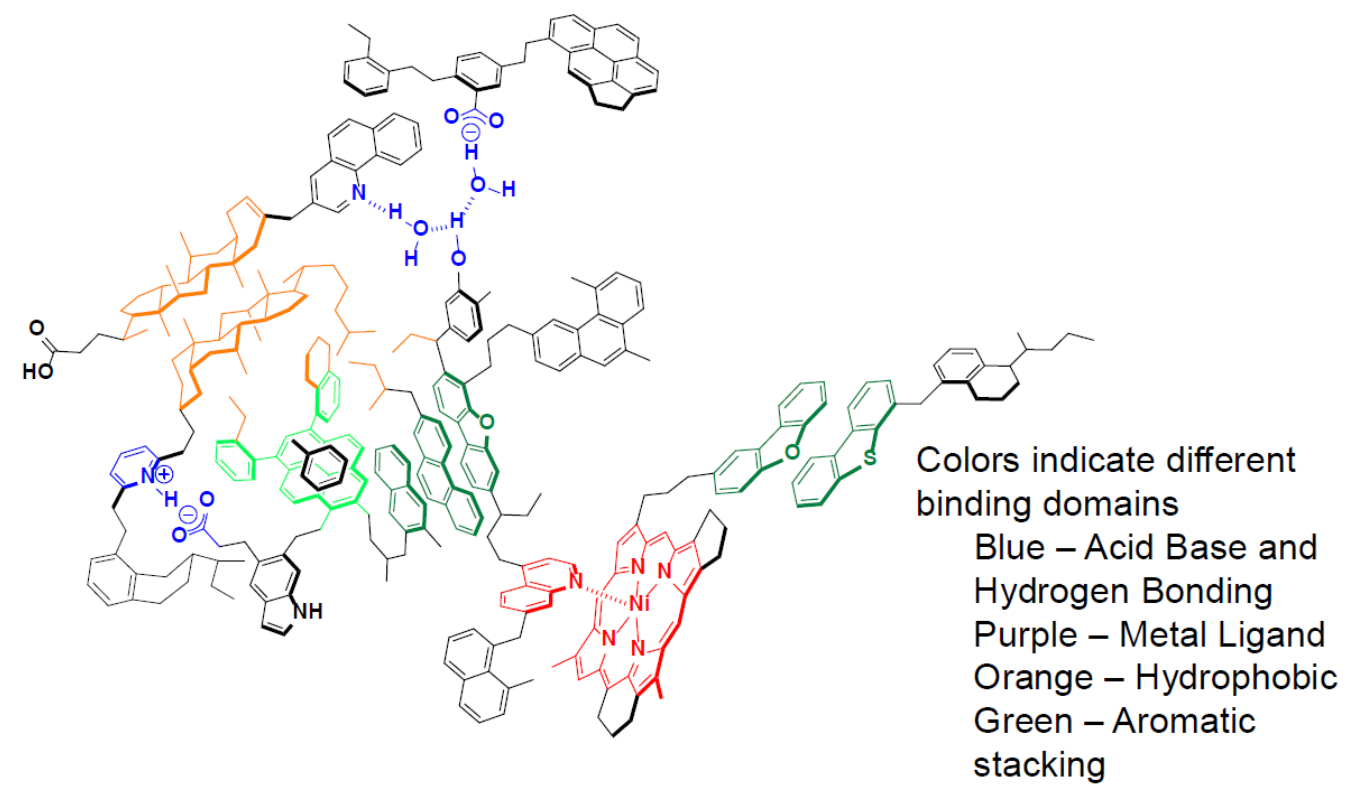

Figure 3. The modes of asphaltene aggregation (Gray, 2011).

The oil can be viewed as a multicomponent system consisting of asphaltenic macromolecules dispersed in a mixture of different components (Garreto, 2011). To better understand the role of solvents in the process of disaggregation of asphaltenes extracted from vacuum residues and evaluate their tendency to dissociate under different conditions, Carauta et al. (2005) used molecular modeling to study the effect of solvents and their combinations on asphaltenic aggregates. One advantage of the computational calculation is the fact that this technique can indicate the potential of the molecules employed in stabilizing particular asphaltenes. These calculations can also provide information about transition states and unstable species, sometimes inaccessible experimentally (Quintero, 2009). Modeling studies play an important role in the investigation of aggregation processes and identification of the interactions involved (Carauta et al., 2005).

Besides the standard technique, IP - 143 or ASTM6560-00, several authors have used alternative techniques or modified IP for extraction and characterization of asphaltenic fractions. Table 2 shows some alternative methods of obtaining asphaltenes from residues and their peculiarities reported in the literature.

Table 2. Alternative methods for extraction of asphaltenes.

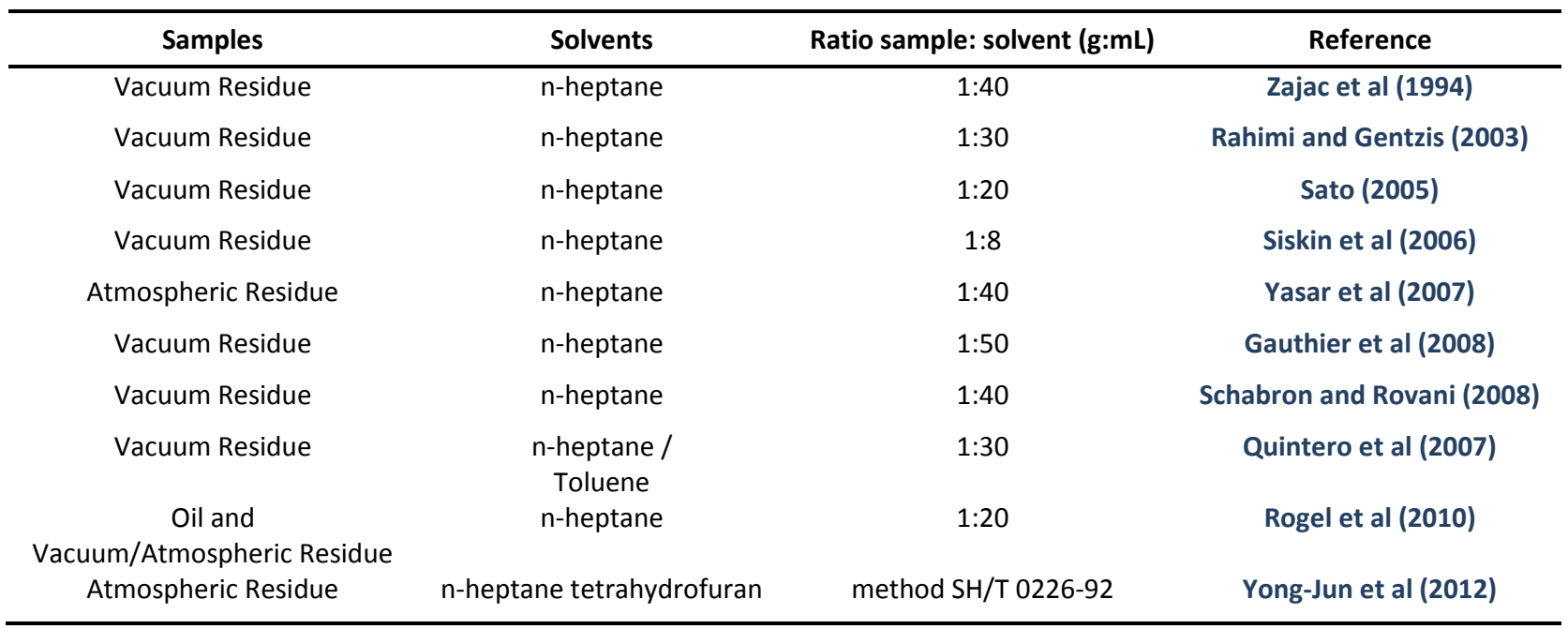


Table 3. Characteristics of crude oils.

\begin{tabular}{cccccccc}
\hline Type of oil & ${ }^{\circ} \mathbf{A P I}$ & $\begin{array}{c}\text { S content } \\
(\mathbf{w t} \%)\end{array}$ & $\begin{array}{c}\mathbf{N} \\
(\% \mathrm{p} / \mathbf{p})\end{array}$ & $\begin{array}{c}\text { Asphaltene } \\
(\% \mathrm{p} / \mathbf{p})\end{array}$ & $\begin{array}{c}\text { Acidity }(\mathbf{m g} \\
\text { KOH/g) }\end{array}$ & $\mathbf{N i}(\mathbf{p p m})$ & $\mathbf{V}(\mathbf{p p m})$ \\
\hline A & 19 & 0.7 & 0.5 & 2.6 & 1.0 & 19.0 & 24.0 \\
B & 25 & 0.8 & 0.3 & 2.8 & 0.8 & 9.0 & 12.0 \\
\hline
\end{tabular}

\section{MATERIALS AND METHODS}

The samples used in this study are vacuum distillation residues from two different types of Brazilian oil, one considered heavy (A) and the other medium (B) (Table 3). Asphaltenes were extracted by an alternative technique referred to as EQ/NP, developed by our group and also by the IP-143 technical standard.

\subsection{Extraction of asphaltenes}

The authors of this work have been developing procedures for asphaltene fractionation and characterization based on alternative technique employed to separate asphaltenes from vacuum residues (VR) obtained from off-shore fields (Moura et al., 2009; Silva et al., 2010). This extraction technique employs a naphthenic solvent, cyclohexane (N) (analytical grade), in combination with two paraffinic solvents (analytical grade) referred to as $P_{1}$ ( $n$-pentane) and $P_{2}$ (n-heptane). The proportion of paraffinic to naphthenic solvent is $85: 15(\mathrm{v} / \mathrm{v})$, while the ratio of sample to solvent is $1: 8$. In a typical procedure, a corresponding amount of sample is added to a $250 \mathrm{ml}$ extractor with the specific solvent blend, and left under magnetic stirring for two hours at room temperature. At the end of this period, the insoluble fraction (asphaltene) is filtered under vacuum and dried in an oven at $80^{\circ} \mathrm{C}$. The percentage of asphaltenes is calculated using Equation 2:

$\%$ Asphaltene $=\frac{M_{2}+M_{3}}{M_{1}} \times 100$

Where:

$M_{1}=$ initial mass of the sample

$M_{2}=$ mass of the insoluble fraction retained on the filter paper

$M_{3}=$ mass of insoluble fraction retained in the extractor

\subsection{Characterization of asphaltenes}

\subsubsection{Hydrogen Nuclear Magnetic Resonance $\left({ }^{1} \mathrm{H}-\mathrm{NMR}\right)$}

The sample was dissolved in deuterated chloroform and inserted into $5 \mathrm{~mm}$ tubes. NMR $-{ }^{1} \mathrm{H}$ spectra were obtained using a Varian UNITY-PLUS 7.05 T (300 MHz for ${ }^{1} \mathrm{H}$ ) apparatus. The analysis was carried out in duplicate. The error established for repeatability was of $5 \%$.

\subsubsection{Thermogravimetric analysis (TG/DTG)}

TG/DTG analysis was performed on a PerkimElmer model Pyris TGA analyzer. The temperature ranged from 25 to $700^{\circ} \mathrm{C}$, and heating rate was of $10^{\circ} \mathrm{C} / \mathrm{min}$, under $\mathrm{N}_{2}$ flow of $30 \mathrm{ml} / \mathrm{min}$.

\section{RESULTS AND DISCUSSION}

\subsection{Analysis of asphaltene content}

Vacuum Residues VR-A and VR-B are soluble in a naphthenic hydrocarbon ( $N$ ), at room temperature. For selective extraction of asphaltenes, two paraffinic solvents $P_{1}$ and $P_{2}$, which act as precipitants of asphaltenes, were tested. The solubility parameters of the $\mathrm{NP}_{1}$ and $\mathrm{NP}_{2}$ blends were $15 \mathrm{MPa}^{1 / 2}$ e $16 \mathrm{MPa}^{1 / 2}$, respectively.

The percentages of asphaltenes extracted from samples VR-A and VR-B using EQ / NP and IP-143 techniques are shown in Table 4. This table shows that $\mathrm{NP}_{1}$ worked as a better extractant than $\mathrm{NP}_{2}$ for both samples. The lower the solubility parameter of the blend is, the higher the amount of asphaltenes obtained in the extraction process from the combination of these two solvents will be (Seidl et al., 2010; 2011). Residue A yields the highest concentration of asphaltene by any of the methods tested. 
Table 4. Percentages of asphaltenes obtained by different techniques.

\begin{tabular}{ccc}
\hline Samples & Extraction Techniques & $\begin{array}{c}\text { Percentage of } \\
\text { Asphaltenes (\%) }\end{array}$ \\
\hline \multirow{3}{*}{ VR A } & $\mathrm{EQ} / \mathrm{NP}_{1}$ & $12.5( \pm 0.98)$ \\
& $\mathrm{EQ} / \mathrm{NP}_{2}$ & $5.4( \pm 0.51)$ \\
$\mathrm{IP}-143$ & $11.9( \pm 0.4)$ \\
\hline \multirow{3}{*}{ VR B } & $\mathrm{EQ} / \mathrm{NP}_{1}$ & $7.0( \pm 0.79)$ \\
& $\mathrm{EQ} / \mathrm{NP}_{2}$ & $1.8( \pm 0.19)$ \\
& $\mathrm{IP}-143$ & $9.3( \pm 0.54)$ \\
\hline
\end{tabular}

Table 5. Percentage of types of hydrogen.

\begin{tabular}{|c|c|c|c|c|c|c|}
\hline \multirow{3}{*}{$\begin{array}{l}\text { Types of } \\
\text { Hydrogen }\end{array}$} & \multicolumn{3}{|c|}{ Percentage (\%) * } & \multicolumn{3}{|c|}{ Percentage (\%) * } \\
\hline & \multicolumn{3}{|c|}{ VR-A } & \multicolumn{3}{|c|}{ VR-B } \\
\hline & $\mathrm{EQ} \mathrm{NP}_{1}$ & $\mathrm{EQ} / \mathrm{NP}_{2}$ & IP-143 & $\mathrm{EQ} / \mathrm{NP}_{1}$ & $\mathrm{EQ} / \mathrm{NP}_{2}$ & IP-143 \\
\hline Aromatic & 21.9 & 30.7 & 27.8 & 22.9 & 22.5 & 24.6 \\
\hline $\mathrm{H} \alpha$ & 17.6 & 17.2 & 20.3 & 17.4 & 20.7 & 22.7 \\
\hline$H \beta$ & 31.0 & 38.0 & 33.1 & 28.7 & 29.4 & 34.2 \\
\hline $\mathrm{H} p$ & 29.5 & 14.1 & 18.8 & 31.0 & 27.4 & 18.6 \\
\hline Total saturated & 78.1 & 69.3 & 72.2 & 77.1 & 77.5 & 75.4 \\
\hline
\end{tabular}

*Percentage of peak area.

Comparing the techniques, it is possible to observe that the percentage of asphaltenes obtained for VR-A with $\mathrm{NP}_{1}$ (12.5\%) was slightly higher than that found by the standard method IP $143(11.9 \%)$. These percentages are close to the values found by other researchers 12,8wt.\% (Murugan et al., 2009); 14,2 wt \% (Tanaka et al.,2004); 10,3 wt \% (Quintero, 2009).

\subsection{Compositional group analysis}

The ${ }^{1} \mathrm{H}-\mathrm{NMR}$ results suggest that the species extracted by different techniques are very similar, because the proportions between the different types of hydrogens were close $(\alpha$ - substituents on the aromatic ring; $\beta$ - in the alkyl chain length; and $\gamma$ - in the number of terminal substituents). The different types of carbons and hydrogens are represented in Figure 4.

Table 5 presents the variation of possible compositional groups of asphaltenes obtained by different techniques. Solvent blends $\mathrm{NP}_{1}$ and $\mathrm{NP}_{2}$ may extract asphaltene constituents selectively.

For VR-A, there was a greater percentage of $\mathrm{H}_{\beta}$ to both techniques used for extraction. This may indicate a greater amount of side long chains and, perhaps, a greater number of naphthenic rings. The total percentage of saturated hydrogens is greater with $N P_{1}$, resulting in constituents with higher $\mathrm{H}_{\psi}$, indicating terminal or branching methyl hydrogen. A larger proportion of $\mathrm{H}_{\beta}$ was observed for $\mathrm{NP}_{2}$, suggesting that the molecules had longer side chains than those obtained with $\mathrm{NP}_{1}$, as well as lower substitution on the aromatic ring, which is reflected by the percentage of hydrogen atoms connected to these rings. The extraction of molecular aggregates by solvent blend $\mathrm{NP}_{2}$ is due

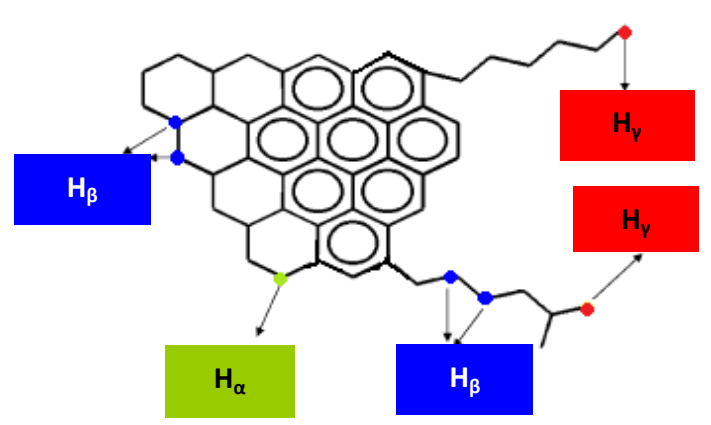

Figure 4. Types of hydrogens (Carauta et al., 2005). 
Table 6. Thermogravimetric data of asphaltenes extracted by different techniques.

\begin{tabular}{|c|c|c|c|c|}
\hline Sample/Technique & $\mathrm{T}_{\text {onset }}\left({ }^{\circ} \mathrm{C}\right)$ & $\mathrm{T}_{\operatorname{Max}}\left({ }^{\circ} \mathrm{C}\right)$ & $\mathrm{T}_{\text {end }}\left({ }^{\circ} \mathrm{C}\right)$ & Coke (\%) \\
\hline VR-A/IP-143 & 445 & 483 & 512 & 49 \\
\hline VR-B/IP-143 & 432 & 488 & 513 & 47 \\
\hline VR-A/ EQ/NP 1 & 446 & 483 & 512 & 37 \\
\hline VR-B/EQ/NP 1 & 449 & 490 & 515 & 39 \\
\hline VR-A/ EQ/NP 2 & 445 & 486 & 514 & 42 \\
\hline VR-B/EQ/NP 2 & 446 & 490 & 512 & 43 \\
\hline
\end{tabular}

to the increase in its affinity for heavy polyaromatic molecules. A similar result was found by Moura et al. (2009).

$\mathrm{EQ} / \mathrm{NP}$ alternative techniques $\left(\mathrm{NP}_{1}\right.$ and $\left.\mathrm{NP}_{2}\right)$ observed similarity in the percentage of $\mathrm{H} \alpha$, but for $\mathrm{H} \gamma$ there was a larger percentage for $\mathrm{NP}_{1}$ (29.5\%). This difference demonstrates that the blend $\mathrm{NP}_{1}$ may, possibly, favor the extraction of molecules with a greater percentage of chain terminals. This percentage for $\mathrm{NP}_{1}$ was also higher than that found for the IP-143 technical standard (18.8\%). For VR-B, the extraction by IP-143 showed more aromatic percentage than EQ/ NP techniques.

Even varying the type of paraffinic solvent, the constituents extracted from both are very similar because the percentages of saturated and aromatic hydrogens are close.

Fractions containing larger proportions of $\mathrm{H \alpha}$ were obtained using the IP-143 method for VR-A residue, indicating that asphalthenic molecules are more substituted on the rings than those obtained by $\mathrm{EQ} / \mathrm{NP}_{1}$ and $\mathrm{EQ} / \mathrm{NP}_{2}$ techniques. Nevertheless, the constituents obtained from RV-A with $\mathrm{NP}_{2}$ had a larger proportion of aromatic hydrogens.

\subsection{Thermal analysis}

The asphaltenic fractions obtained by different techniques showed similar thermal behavior. Figures 5, 6 and 7 shows the graphics of TG/DTG of asphaltenes obtained from VR-A residue using the different extraction techniques.

The onset temperature (Tonset), the temperature of maximum degradation rate (Tmax), and the end temperature (Tend), as well as the percentage of carbonaceous residue (coke) formed in the degradation process are displayed in Table 6.

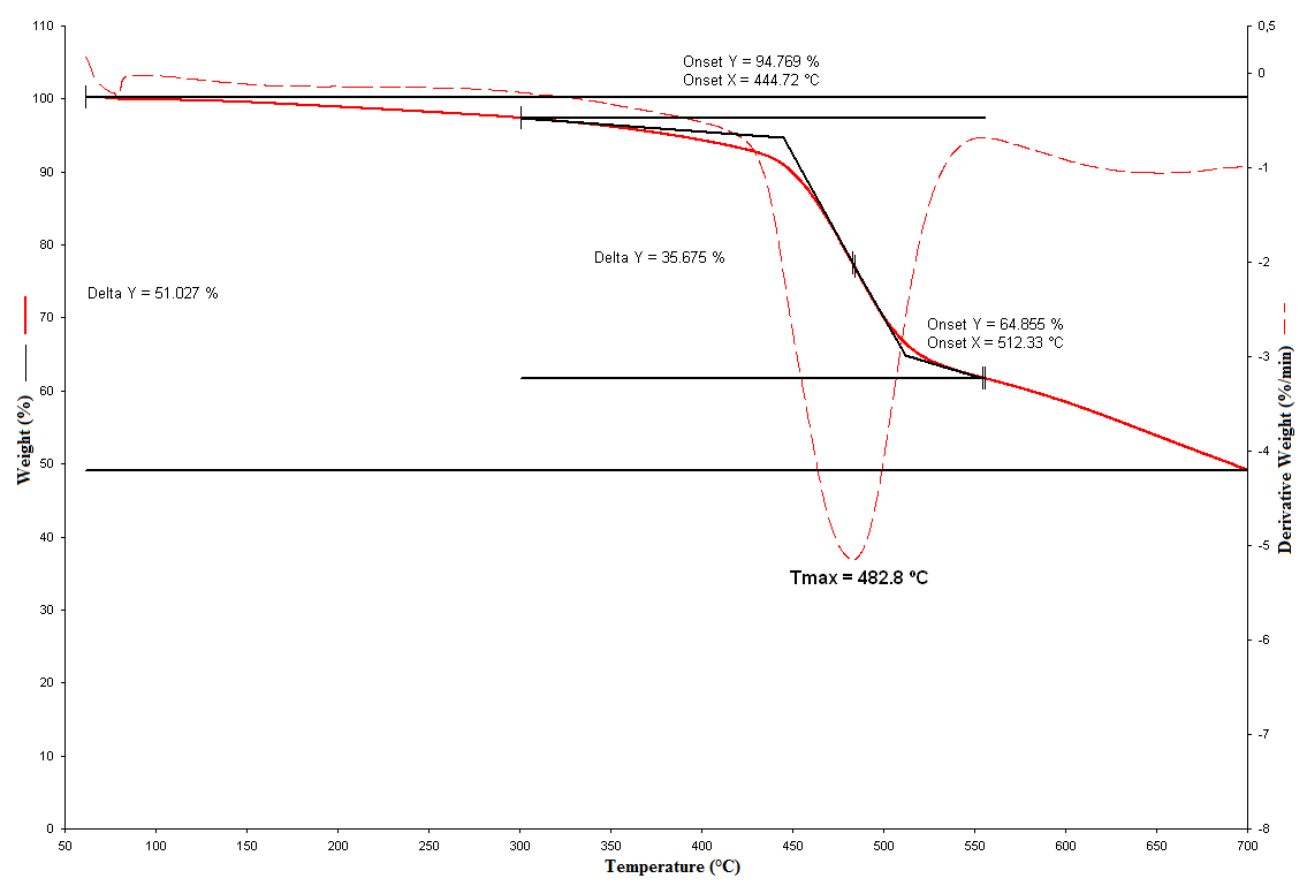

Figure 5. TG/DTG curve of asphaltenes obtained from VR-A residue using IP-143 technique. 


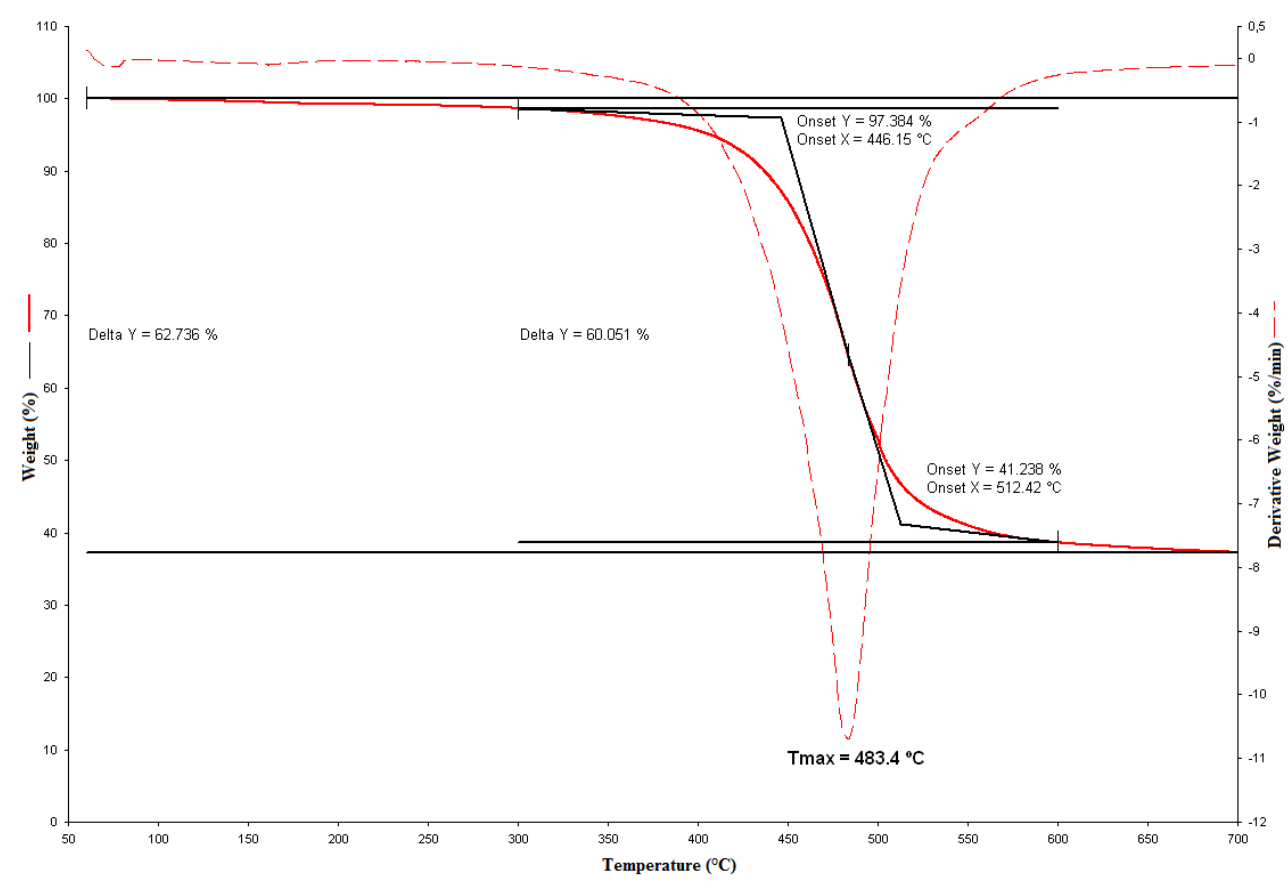

Figure 6. TG/DTG curve of asphaltenes obtained from VR-A residue using EQ/NP 1 technique.

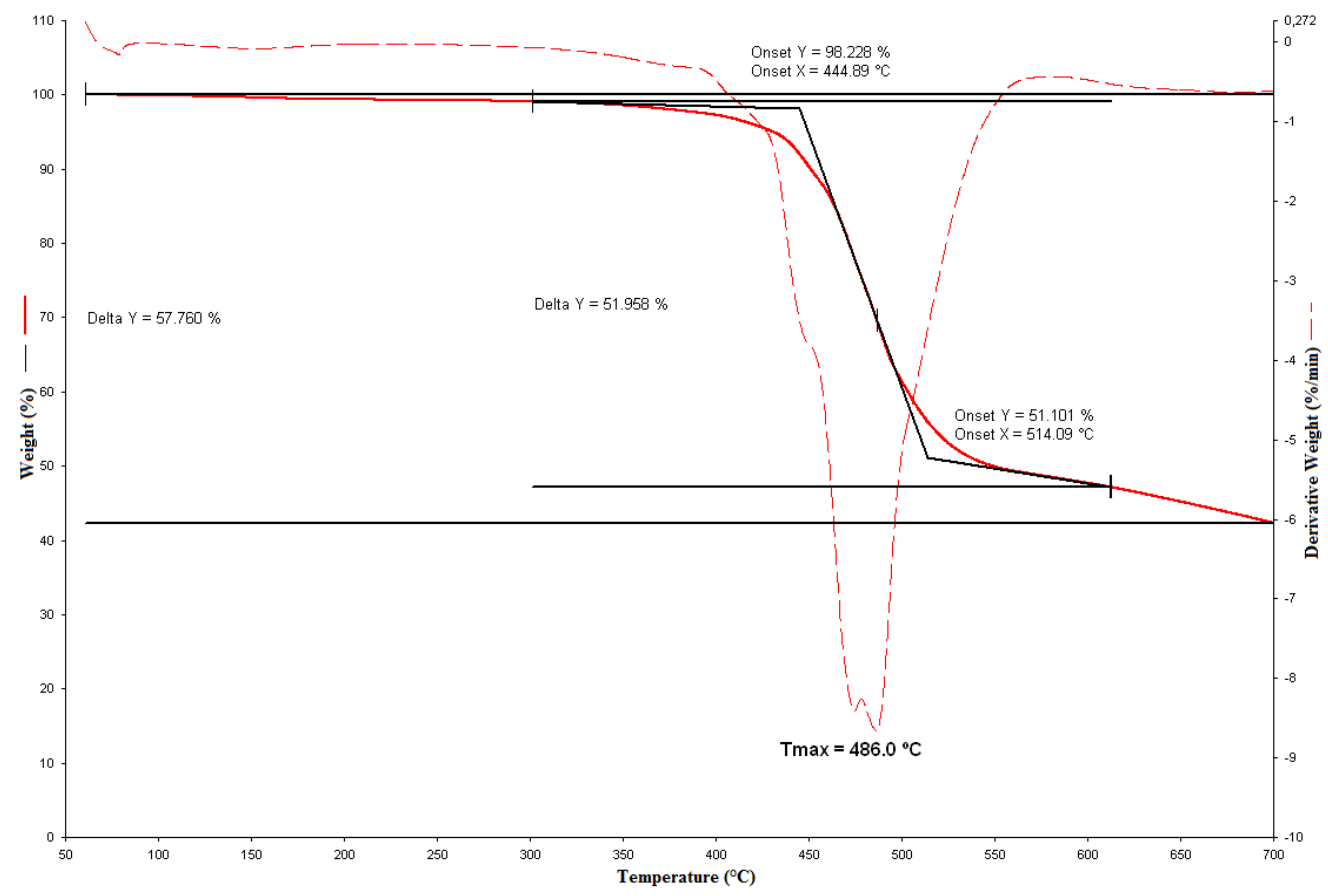

Figure 7. TG/DTG curve of asphaltenes obtained from VR-A residue using EQ/NP 2 technique.

All asphaltene samples showed a maximum peak of degradation in the range of 480 to $490^{\circ} \mathrm{C}$. The percentage of coke formed in the pyrolysis process was in the range of $36 \%-50 \%$. The maximum degradation temperatures and the percentage of coke formed in $\mathrm{N}_{2}$ atmosphere were within the ranges commonly reported in the literature for asphaltenes from different oils/residues (Trejo et al., 2010; Murugan et al., 2009; Gonçalves et al., 2007; Karimi et al., 2011; Juyal et al., 2013). 


\section{CONCLUSIONS}

The percentage of asphaltenes extracted by the $\mathrm{EQ} / \mathrm{NP}_{1}$ alternative solvent blend technique was higher than that obtained by $\mathrm{EQ} / \mathrm{NP}_{2}$ technique. Even when varying the type of paraffin solvent, the constituents extracted of the residue were very similar, as evidenced by the fact that the total percentage of saturated and aromatic hydrogens was similar.

The study of the selective precipitation is still in progress and will be the object of future work. The $\mathrm{EQ} / \mathrm{NP}$ alternative technique can replace the standard method, IP-143, for extraction of the specific types of oils studied in this work. This technique has some advantages if compared to the IP-143 method: it requires less time to extract and reduces energy costs because it does not require prolonged heating. In addition, it uses naphthenic solvents that are less toxic and more environmentally friendly.

The asphaltenes extracted using the different techniques showed similar thermal behavior, with an average maximum degradation peak at $487^{\circ} \mathrm{C}$, and an average percentage of coke of $43 \%$.

The island architecture of asphaltenes extracted using IP-143 technical standard was previous determined by authors of this work (Carauta et al., 2005). Molecular modeling with the fractions obtained by EQ/NP technique is in progress.

\section{ACKNOWLEDGMENTS}

The authors thank CAPES for a doctoral fellowship for Fernanda Barbosa da Silva and CNPq for a research fellowship for Peter Rudolf Seidl.

\section{REFERENCES}

Agência Nacional de Petróleo, Gás e Biocombustíveis. Portaria no 09/2000. Available at: www.anp.com.br Accessed on: 20 April 2013. 2012. (in Portuguese)

Albuquerque, F.O; Nicodem, D.E.; Rajagopal, K. Estudo da Agregação de Asfaltenos por Espectroscopia de Fluorescência. $3^{\circ}$ Congresso Brasileiro de P\&D em Petróleo e Gás, 2005. (in Portuguese)
Ancheyta, J.; Trejo, F.; Rana, M.S. Chemical Transformation during Hydroprocessing of Heavy Oils. Chapter 4, CRC Press, 205-283, 2010. http://dx.doi.org/10.1201/9781420066319-c4

Aske, N.; Kallevik, H.; Sjo"blom, J. Determination of Saturate, Aromatic, Resin, and Asphaltenic (SARA) Components in Crude Oils by Means of Infrared and Near-Infrared Spectroscopy. Energy Fuels, V.15, 1304-1312, 2001. http://dx.doi.org/10.1021/ef010088h

Calemma, V.; Rausa, R.; D'antona, P.; Montanari, L. Characterization of Asphaltenes Molecular Structure. Energy Fuels, 12 (2), 422-428; 1998. http://dx.doi.org/10.1021/ef9701854

Carauta, A.N.M; Seidl, P.R; Chrisman, E. C. A. N; Correia, J. C. G.; Menechini, P. O; Silva, D. M., Leal, K. Z.; Menezes, S. M. C., Souza, W. F.; Teixeira, M. A. G. Modeling Solvent Effects on Asphaltene Dimers. Energy \& Fuels, 19 (4), pp 1245-1251, 2005. http://dx.doi.org/10.1021/ef049809d

Dickie, J.P; Yen, T.F. Macrostructures of asphaltic fractions by various instrumental methods. Analytical Chemistry. V. 39 (14), pp 1847-1852, 1967. http://dx.doi.org/10.1021/ac50157a057

Garreto, M. S. E. Influência do Parâmetro de Solubilidade Sobre a Estabilidade de Asfaltenos no Petróleo. 259f. Tese de Doutorado. Programa de Pós Graduação em Tecnologia de Polímeros, Universidade Federal do Rio de Janeiro/IMA, 2011. (In Portuguese)

Gauthier, T.; Danial-Fortain, P.; Merdrignac, I.; Guibard, I.; Anne-Agathe, Q. Studies on the evolution of asphaltene structure during hydroconversion of petroleum residues. Catalysis Today, v.130, 429-438, 2008. http://dx.doi.org/10.1016/i.cattod.2007.10.005

Gonçalves, M.L.A.; Ribeiro, D.A.; Teixeira, A.M.R.F.; Teixeira, M.A.G. Influence of asphaltenes on coke formation during the thermal cracking of different Brazilian distillation residues. Fuel, V. 86 (4), 619-623, 2007.

http://dx.doi.org/10.1016/j.fuel.2006.08.022

Goual, L.; Firoozabadi, A. Measuring Asphaltenes and Resins, and Dipole Moment in Petroleum Fluids. AIChE Journal. V. 48(11), 2646 2663, 2002. http://dx.doi.org/10.1002/aic.690481124 
Goual, L.; Sedghi, M. ; Zeng, H. ; Mostowfi, F. ; McFarlane, R. ; Mullins, O. C. On the formation and properties of asphaltenes nanoaggregates and clusters by DC-conductivity and centrifugation. Fuel, v.90, p. 2480-2490, 2011.

http://dx.doi.org/10.1016/i.fuel.2011.02.025

Gray, M. Oilsands and the role of Asphaltenes at the Interface. Centre for Oilsands Innovation at the University of Alberta. Department of Chemical and Materials Engineering, 2011.

Hernández, M.; Alberto, J.; Jorge, A. Current Knowledge and Potential Applications of Ionic Liquids in the Petroleum Industry, lonic Liquids: Applications and Perspectives, Prof. Alexander Kokorin (Ed.), ISBN: 978-953-307-248-7, InTech, 2011.

Hildebrand, J. H.; Prausnitz, J. M.; Scott, R. L. Regular Solutions. Van Nostrand-Reinhold, New York, 1970.

IP $143 / 90$ ou ASTM 6560. Asphaltene (Heptane Insolubles) in Petroleum Products, in Standards for Petroleum and its Products - Institute of Petroleum, London, pp. 143.1-143.7, 1990.

Juyal, P.; McKenna, A. M.; Fan, T.; Cao, T.; Velásquez, R. I. R.; Fitzsimmons, J. E.; Yen, A.; Rodgers, R. P.; Wang, J.; Buckley, J.S.; Gray, M. R.; Allenson, S. J.; Creek, J. Joint Industrial Case Study for Asphaltene Deposition. Energy \& Fuels, 27 (4), pp 1899-1908, 2013.

Karimi, A.; Qian, K.; Olmstead, W. N.; Freund, H.; Yung, C.; Gray, M. R. Quantitative Evidence for Bridged Structures in Asphaltenes by Thin Film Pyrolysis. Energy Fuels, 25 (8), pp 3581-3589, 2011. http://dx.doi.org/10.1021/ef200518g

Kelland, M. A. Production Chemicals for the Oil and Gas Industry. 1. ed. CRC Press: s.n., v. 72, Chapter 4. Asphaltene Control, 2009.

Moura, M. B. R., Guimarães, M. J. O. C., Seidl, P. R., Quintero, L. C. N.; Junior, L. C. Extração de Resíduo de Vácuo Utilizando Blends de Solventes Naftênicos e Parafínicos. Petro \& Química, v. 316, p. 30-32, 2009.

Mullins, O. C. The Modified Yen Model. Energy \& Fuels. v. 24, p. 2179- 2207, 2010. http://dx.doi.org/10.1021/ef900975e
Mullins, O.C.; Sabbah, H.; Eyssautier, J.; Pomerantz, A. E.; Barré, L.; Andrews, A.B.; Morales, Y.R.; Mostowfi, F.; McFarlane, R.; Goual, L.; Lepkowicz, R.; Cooper, T.; Orbulescu, J.; Leblanc, R.M.; Edwards, J.; Zare, R.N. Advances in Asphaltene Science and the Yen-Mullins Model. Energy \& Fuels, v. 26 (7), 3986-4003, 2012.

Murgich, J. Intermolecular Forces in Aggregates of Asphaltenes and Resins. Petroleum Science and Technology, v.20, 1029-1043, 2002. http://dx.doi.org/10.1081/LFT-120003692

Murugan, P.; Mahinpey, N.; Mani, T. Thermal cracking and comustion kinetics of asphaltenes derived from Fosterton oil. Fuel Processing Technology, V. 90 (10), 1286-1291, 2009. http://dx.doi.org/10.1016/j.fuproc.2009.06.008

Navarro, L.C.; Seidl, P.R.; Silva, F.B.; Guimarães, M.J.O.C,; Tasic, L.; Leal, K.Z.; Menezes, S.M.C. Fractionation of constituents of asphaltene residues. Petrophase, P-79, 2012.

Quintero, L.C.N. Fracionamento e análise de asfaltenos extraídos de petróleos brasileiros. 186f. Tese de Doutorado. Programa de Pós Graduação em Tecnologia Química e Bioquímica, Universidade Federal do Rio de Janeiro, 2009. (In Portuguese)

Quintero, L.C.N.; Seidl, P.R; Tasic L.; Leal, K.Z.; Menezes, S.M.C.; Nunes, E. C. A. Caracterização de subfrações de asfaltenos de resíduos de vácuo obtidas usando misturas heptano-tolueno (heptol). 4ㅇ Congresso Brasileiro de Pesquisa e Desenvolvimento em Petróleo a Gás, Campinas, 2007.

Rahimi, P. M.; Gentzis, T. Thermal Hidrocraking of Cold Lake Vacuum Bottoms Asphaltenes and Their Subcomponents. Fuel Processing Technology, V. $80,69-79,2003$. http://dx.doi.org/10.1016/S0378$\underline{3820(02) 00223-0}$

Ramírez, F.A.; Moralez, Y.R. Island versus Archipelago Architecture for Asphaltenes: Polycyclic Aromatic Hydrocarbon Dimer Theoretical Studies. Energy Fuels, 27 (4), pp 1791-1808, 2013. http://dx.doi.org/10.1021/ef301522m

Rogel, E. J.; Ovalles, C.; Moir, M. Asphaltene Stability in Crude oils and Petroleum materials by Solubility Profile Analyses. Energy Fuels, v.24 (8), p.4369 - 4374, 2010. http://dx.doi.org/10.1021/ef100478y 
Rogel, E.; León, O.; Y. Espidel, Pdvsa-Intevep, González, Y.; Metropolitana, U. Asphaltene Stability in Crude Oils. SPE Production \& Facilities. V. 16(2), 84-88, 2001.

http://dx.doi.org/10.2118/72050-PA

Sato, S.; Takanohashi, T.; Tanaka, R. Structural Analysis of a Fused Aromatic Ring System by the Combination of 13C-NMR and DEPT Techniques. $222^{\text {nd }}$ ACS National Meeting, Fuel Chemistry Division Preprints, v.46 (2), 353-354, 2005.

Schabron, J. F.; R., Joseph, F. JR. On-column precipitation and re-dissolution of asphaltenes in petroleum residual. Fuel, v. 87, 165-176, 2008. http://dx.doi.org/10.1016/j.fuel.2007.04.024

Seidl, P. R. ; Chisman, E. C. A. N. ; Carvalho, C. C. V. ; Leal, K. Z. ; Menezes, S. M. C. NMR analysis of asphaltenes separated from vacuum residues by selected solvents. Journal of Dispersion Science and Technology, v. 25 (3), p. 349-353, 2004. http://dx.doi.org/10.1081/DIS-120037689

Seidl, P. R.; Silva, F. B.; Guimaraes, Maria José O. C. ; Leal, K. Z. . Analysis of Asphaltenes Extracted from a Heavy Brazilian Crude Oil by Solvent Mixtures. Petrophase, v. 1. p. 63-64, 2011.

Seidl, P.R.; Silva, F.B.; Guimarães, M.J.O.C.; Costa, M.P.M.; Nasser, S. Selective extraction of asphaltene from Brazilian heavy oils by solvente blends, Abstract P2-43, Petrophase, 2010.

Silva, F. B.; Guimarães, M. J. O. C.; Seidl, P. R.; Leal, K. Z. Extração seletiva de constituintes de petróleos pesados brasileiros. Petro \& Química, v. 327, p. 64-66, 2010. (in Portuguese)

Siskin, M.; Kelemen, S. R.; Eppig, C. P.; Brown, L. D.; Afeworki, M. Asphaltene Molecular Structure and Chemical Influences on the Morphology of Coke Produced in Delayed Coking. Energy \& Fuels , v.20 (3), 1227-1234, 2006.

http://dx.doi.org/10.1021/ef050389h
Speight, J. G. The Chemical and Physical Structure of Petroleum: Effects on Recovery Operations. Journal of Petroleum Science and Enginnering, v22, p3, 1999.

Speight, J. G. The Chemistry and Technology of Petroleum. 4a Edição, Taylor and Francis, Boca Raton, 2006.

http://dx.doi.org/10.1201/9781420008388

Strausz, O.P. Special Section on Asphaltenes. Energy Fuels, v.13 (2), 205-541, 1999. http://dx.doi.org/10.1021/ef990014u

Tanaka, R.; Sato, S.; Takanohashi, J.E; Winans, R.E. Analysis of the Molecular Weight Distribution of Petroleum Asphaltenes Using Laser DesorptionMass Spectrometry. Energy Fuels, 18 (5), 14051413, 2004. http://dx.doi.org/10.1021/ef034083r

Trejo, F.; Rana, M.S.; Ancheyta, J. Thermogravimetric determination of coke from asphaltenes, resins and sediments and coking kinetics of heavy crude asphaltenes. Catalysis Today, V. 150 (2-3), 272-278, 2010. http://dx.doi.org/10.1016/j.cattod.2009.07.091

Yasar, M.; Akmaz, S.; Gurkaynak, A. M. Investigation of glass transition temperatures of Turkish asphaltenes. Fuel, v.86, p. 1737-1748, 2007. http://dx.doi.org/10.1016/j.fuel.2006.12.022

Yong-Jun, L. Microstructure Characterization os Asphaltenes from atmospheric residue before and after Hydroprocessing. Journal Fuel Chemistry Technology, v. 40 (9), 1086-1091, 2012. http://dx.doi.org/10.1016/S1872-5813(12)60039-5

Zajac, G. W.; Sethi, N. K. Joseph, J. T. Molecular Imaging of Petroleum Asphaltenes by Scanning Tunneling Microscopy: Verification of Structure from ${ }^{13} \mathrm{C}$ and Proton Nuclear Magnetic Resonance Data. Scanning Microscopy, V.8, 463-470, 1994. 